\title{
Jean E. Jackson, Managing Multiculturalism: Indigeneity and the Struggle for Rights in Colombia
}

\author{
Stanford: Stanford University Press, 2019, 308 pp. \\ ISBN: 9781503607699
}

\section{Marcela Velasco / Colorado State University}

In her newest book, Jean Jackson explores the changing views on indigeneity in Colombia. A recently coined word, indigeneity refers to the timeworn practice of appropriating, defining, or delimiting who is indigenous and naming the sources of this identity (22-24). As the title of the book suggests, this practice is often managed by different types of powerbrokers, authorities, and activists, and is usually observable during episodes of contention. Controversies over authenticity (what is indigenous) and authority (who has the power or knowledge to decide this) are visible in disputes over indigenous rights, culture, or representation. To illustrate how indigeneity is used or understood by different actors, Jackson identifies specific episodes of transformative change, such as the 1991 Constitution that introduced multicultural rights, Constitutional Court rulings on special indigenous jurisdictions, or efforts by local communities to re-create a lost indigenous identity in order to gain recognition as indigenous authorities.

The work makes several contributions. It introduces key debates in the field of indigenous studies in Colombiawhich are largely written in Spanish - for unfamiliar scholars. These readers, however, should consider that much of the Colombian literature focuses on political activism in the Andean region, particularly in the Cauca department, recognized as Colombia's most influential indigenous movement, with widespread impact on domestic multicultural policies and politics.

Students of anthropology should benefit from Jackson's theoretically grounded observations of her ethnographic methods and personal strategies to adapt to changes in her field and in Colombian politics. Her fieldwork began in the late 1960s in the Vaupés region of the Amazon lowlands where she studied Tukanoan "linguistic exogeny," a cultural complex requiring people to marry outside their communities and linguistic groups (7). But as Tukano society began to face increasing pressures from missionaries, drug traffickers, new settlers, and a growing state presence, the prevalent anthropological categories failed to explain the effects of these events on culture.

Grassroots indigenous organizing in the 1960s and 1970s, and the foundation of the Cauca Regional Indigenous Council in 1971, ushered in a new era of transformative political and cultural change. In the Vaupés region, Catholic missionaries founded the Vaupés Indigenous Regional Council (CRIVA) in 1973, ostensibly to defend indigenous communities against emerging threats, but also to limit the influence of New Tribes missionaries in the region. The CRIVA cultivated a new type of Tukanoan leadership that presented its own vision of Tukano culture to outsiders. Jackson's first reaction to these new leaders was that they produced "inauthentic [...] representations of Tukanoan culture [which compelled her] to confront a situation in which culture was being politicized, something my graduate school training did not prepare me for at all" (21).

At this point, Jackson shifts her attention to the "ever-increasing role played by indigenous culture in struggles taking place throughout the country aimed at securing rights and the resources that accompany official recognition of those rights" (9). This episode altered the nature of her scholarly expertise from traditional ethnographic work that describes a cultural complex to the study of social movements and the analysis of cultural politics.

For scholars more familiar with Colombian multiculturalism, Jackson outlines key moments of conflict and deliberation that challenged or reshaped prevailing notions of indigeneity. In particular, she offers key insight into state building in Colombia's old territories and the political incorporation of indigenous people in the country's periphery, a topic that has been less studied in the literature. Jackson also contributes to the study of the era of reforms starting in the 1980s that recognized ethnic minority rights to collective land tenure, self-government, protections of culture, and control of development (60). Though the reforms enabled indigenous people and Afro-Colombians by granting them formal ownership of over $30 \%$ of the country's territory and recognizing them as local authorities, their agency was curtailed by government efforts to shape "identity politics with an aim to co-opt activists and transform them into "docile subjects"' (60).

To elaborate on this point, Jackson analyses a few important episodes such as the 1996 occupation of government offices to protest the Division of Indigenous Affairs'(DAI) decision 
to undermine a non-governmental organization's claim to be authentic representatives of the Wayuu people in the Guajira department. In this dispute, the DAI argued that its mandate was to strengthen traditional institutions by working with local indigenous authorities or legitimate community representatives. The National Indigenous Organization of Colombia and other national and regional groups soon joined forces and expanded the takeovers to other parts of the country in order to fight for their right to "maintain their near-monopoly as intermediaries" of indigenous rights (130). Jackson documents the various sides involved in this debate, including government, key personalities in the indigenous movement, and other organizations. The conflict was partly resolved by the establishment of key coordination instances for indigenous social movement organizations and government to meet. However, the government failed to enable the special indigenous jurisdictions (entidades territoriales indigenas) the most necessary step to formally empower, and perhaps "legitimate" local indigenous authorities in their territories.

Though the work does not assess a specific argument or weigh-in on a particular theoretical debate or puzzle in its field, it does offer valuable insight on indigenous politics in Colombia. Jackson expertly deploys the concept of indigeneity to tie together a broader reflection on the evolution of her "object of study, methodology, and theoretical approach" (9) and reviews in great detail over four decades of rights development and indigenous cultural politics. Throughout the manuscript, Jackson weaves theoretical insights into ethnographic observations of the fluid and evolving nature of indigeneity as different claimants and powerbrokers contest their right to define indigenous culture, and "manage" the boundaries of indigenous rights and identity in Colombia. 